\title{
ANALISIS DAN EVALUASI REKOMENDASI E-LEARNING BERBASIS OPEN SOURCE (STUDI KASUS: SMKN XYZ BANDUNG)
}

\author{
Arief Samuel Gunawan, Herastia Maharani, Karen K. Tatuh \\ Departemen Sistem Informasi, Institut Teknologi Harapan Bangsa \\ Jl. Dipatiukur 80 - 84, Bandung, Indonesia \\ E-mail : arief@ithb.ac.id, herastia@ithb.ac.id, karentatuh.07@gmail.com
}

\begin{abstract}
SMKN XYZ is a vocational institution located in Bandung. In performing learning activities, SMKN XYZ implemented e-learning systems, namely Edmodo and school website, to complement and support daily learning activities. E-learning system is used as a solution when teachers could not attend the class. But in reality, it was found that both Edmodo and school website have relatively similar features and functions in use. Furthermore, it was found from interviews and questionnaire results that both existing applications were lacking of several necessary features such as chatting and math equation features. Therefore, an analysis and evaluation of e-learning system recommendation will be conducted in this research. There are 5 main requirements of SMKN XYZ regarding e-learning implementation, which were found from the interviews and questionnaire, namely learning material online sharing, online discussion, online assignment, online quiz and online announcement. Moodle is a web-based open source elearning application. Using Moodle could support online learning activities and meet the 5 main requirements of SMKN XYZ, by providing features such as access to learning materials, assignment, quiz, discussion and other important informations, including chatting and math equation features which were not available in Edmodo and school website.
\end{abstract}

Keywords: Online Learning Activities, Open Source E-Learning, Moodle.

\begin{abstract}
Abstrak
SMKN XYZ adalah salah satu instansi pendidikan yang berlokasi di Bandung. Dalam menjalankan kegiatan belajar-mengajar, SMKN XYZ menerapkan sistem e-learning sebagai pendukung pembelajaran di kelas, yaitu Edmodo dan website sekolah. Sistem $e$ learning diterapkan sebagai solusi ketika guru berhalangan hadir untuk memberi materi pelajaran di kelas. Namun pada penggunaannya ditemukan bahwa Edmodo dan website sekolah memiliki fitur dan fungsi yang relatif sama. Selain itu dari hasil wawancara dan kuesioner, didapatkan bahwa kedua aplikasi tersebut masih kekurangan fitur yang diperlukan seperti fitur chatting dan math equation. Oleh karena itu pada penelitian ini dilakukan analisis dan evaluasi rekomendasi sistem e-learning yang dapat membantu pihak sekolah. Berdasarkan hasil wawancara dan kuesioner didapatkan 5 kebutuhan utama yang dibutuhkan SMKN XYZ berkaitan dalam penggunaan e-learning, yaitu: pemberian materi online, diskusi online, penugasan online, kuis online dan pengumuman online. Moodle merupakan sebuah aplikasi e-learning open source berbasis web. Penggunaan Moodle dapat mendukung kegiatan pembelajaran online dan memenuhi 5 kebutuhan utama SMKN XYZ, dengan menyediakan fitur-fitur yang dibutuhkan seperti akses terhadap materi belajar, tugas, kuis, diskusi online juga informasi penting lainnya, termasuk fitur-fitur yang tidak tersedia pada Edmodo dan website sekolah, seperti fitur chatting dan math equation.
\end{abstract}

Kata kunci: Online Learning Activities, Open Source E-Learning, Moodle. 


\section{Pendahuluan}

Sekolah Menengah Kejuruan merupakan tahap dimana murid dibagikan berbagai pengetahuan, keterampilan dan pengalaman sehingga mampu melakukan pekerjaan tertentu yang dibutuhkan, baik bagi dirinya, bagi dunia kerja, maupun bagi pembangunan bangsanya.

Berdasarkan hasil observasi dan wawancara ditemukan bahwa pembelajaran melalui tatap muka di kelas saja memiliki kekurangan khususnya ketika guru tidak dapat hadir dikarenakan tugas dinas ke luar kota ataupun halangan lainnya atau ketika ada agenda kegiatan sekolah lainnya yang memotong jam pelajaran di kelas. Hal ini berakibat materi pelajaran yang seharusnya disampaikan oleh guru di kelas tidak terlaksana, sehingga diperlukan metode pembelajaran yang dapat mengatasi keterbatasan waktu belajar, yaitu pembelajaran yang dilakukan secara jarak jauh melalui penggunaan e-learning. Dimana dengan penerapan proses pembelajaran dengan e-learning ini proses pembelajaran tidak hanya harus dilakukan dengan pertemuan di kelas. Selain itu, dengan menggunakan metode pembelajaran ini siswa dapat berdiskusi dengan guru tanpa harus dibatasi oleh ruang dan waktu.

Untuk mengatasi masalah tersebut, SMKN XYZ Bandung telah menerapkan beberapa sistem informasi dan aplikasi yang digunakan dalam mendukung proses pembelajaran, seperti portal bagi guru dan siswa berupa website sekolah. Pada website ini tersedia informasi, berita dan pengumuman bagi siswa dan guru, serta bahan dan materi pembelajaran tersedia untuk para siswa. Selain itu, di website ini juga siswa dapat melakukan absensi dan ujian secara online dan beberapa fitur lainnya. Selain website sekolah, SMKN XYZ Bandung juga menggunakan jejaring sosial untuk dunia pendidikan, Edmodo (www.edmodo.com), sebagai wadah komunikasi antara guru dan siswa, seperti forum yang dimanfaatkan sebagai ruang diskusi dan postingan materi pembelajaran yang diposting ketika guru mata pelajaran tertentu berhalangan untuk hadir dan memberikan pelajaran di sekolah.

Untuk mengatasi masalah tersebut, SMKN XYZ Bandung telah menerapkan beberapa sistem informasi dan aplikasi yang digunakan dalam mendukung proses pembelajaran, seperti portal bagi guru dan siswa berupa website sekolah. Pada website ini tersedia informasi, berita dan pengumuman bagi siswa dan guru, serta bahan dan materi pembelajaran tersedia untuk para siswa. Selain website sekolah, SMKN XYZ Bandung juga menggunakan jejaring sosial untuk dunia pendidikan, Edmodo (www.edmodo.com), sebagai wadah komunikasi antara guru dan siswa, seperti forum yang dimanfaatkan sebagai ruang diskusi dan tempat pengunggahan materi pembelajaran yang diunggah ketika guru mata pelajaran tertentu berhalangan untuk hadir dan memberikan pelajaran di sekolah.

Namun kenyataannya sistem informasi yang diterapkan masih ditemukan kekurangan dan penggunaannya belum maksimal ataupun terdapat duplikasi. Seperti misalnya fitur penyebaran informasi, penugasan dan forum diskusi yang ada baik di website sekolah dan Edmodo. Selain itu, siswa malas mengecek kedua media pembelajaran online tersebut sehingga akhirnya siswa tidak mendapatkan informasi yang diposting guru, sehingga akhirnya untuk memastikan siswa mendapatkan informasi tersebut guru harus kerja dua kali dengan memposting file dan informasi lainnya baik di Edmodo maupun web sekolah..

Berdasarkan kebutuhan SMKN XYZ Bandung dan dengan membandingkan website sekolah dan Edmodo, masalah ini dapat diatasi dengan menerapkan e-learning yang semakin marak di berbagai institusi dan lembaga pendidikan, dimana e-learning dapat membantu mendukung kegiatan belajar-mengajar sebagai pelengkap proses pembelajaran konvensional karena sekarang ini banyak terdapat aplikasi e-learning yang memiliki fitur-fitur yang dapat mendukung kegiatan belajar-mengajar di SMKN XYZ Bandung.

\section{Studi Literatur}

\section{A. E-Learning}

E-learning adalah sistem pendidikan yang menggunakan aplikasi elektronik untuk mendukung belajar mengajar dengan media internet, jaringan komputer maupun komputer stand alone. Terdapat 3 fungsi urama dari elearning dalam proses pembelajaran yaitu sebagai suplemen yang bersifat pilihan (opsional), bersifat pelengkap (komplemen), atau bersifat pengganti (substitusi)(Siahaan, 2002) :

1. Optional

Apabila para peserta didik memiliki kebebasan untuk memilih apakah akan memanfaatkan materi secara elektronik. Dalam mengakses materi belajar secara elektronik peserta didik tidak diwajibkan, namun bila memilih untuk mengaksesnya akan mendapatkan nilai tambah dalam wawasan dan pengetahuan.

\section{Komplemen}

Materi pembelajaran secara elektronik dapat berfungsi sebagai pelengkap atau komplemen apabila konten yang diberikan dimaksudkan untuk melengkapi materi yang telah didapatkan di kelas. Dalam hal ini konten 
elektronik dapat pula berperan sebagai materi pengayaan (reinforcement) atau remedial dalam mendampingi proses belajar konvensional.

3. Substitusi

Peran materi belajar elektronik telah digunakan secara menyeluruh di NegaraNegara maju. Terdapat tiga opsi untuk siswa dalam memilih cara mengakses materi belajar, yaitu dengan pembelajaran konvesional seluruhnya, sebagian konvensional sebagian $e$ learning, atau penggunaan materi e-learning seluruhnya.

\section{B. Learning Management System (LMS)}

Menurut Ellis (2009) definisi LMS adalah "Learning Managemet System, the basic description is a software application that automates the administration, tracking, and reporting of training events". Ellis juga menjelaskan bahwa LMS adalah sebuah perangkat lunak yang memiliki kegunaan dalam hal administrasi, dokumentasi, sumber materi, serta laporan penyampaian materi belajar secara online yang terhubung ke internet. LMS digunakan untuk kegiatan belajar mengajar yang difasilitasi oleh web dalam setiap aktivitasnya. LMS juga sering direferensikans ebagai platform e-learning atau Learning Content Management System (LCMS).

\section{Modular Object-Oriented Dynamic Learning Environment (Moodle)}

Moodle merupakan salah satu bentuk Learning Management System (LMS) atau Course Management System (CMS) yang berbasis open soure. Selain itu Moodle juga ternasuk dalam kategori Virtual Learning Environment (LVE). Dewasa ini Moodle cukup popular digunakan di kalangan akademik sebagai sarana pengembangan website yang dinamis untuk interaksi siswa dan guru. Moodle perlu diinstall pada sebuah web server kemudian dapat diakses oleh komunitas penggunanya. Bari para pengajar moodle menjadi media yang dapat dimanfaatkan untuk mengatur dan mempromosikan proses pembelajaran. Moodle dapat dimanfaatkan dalam kegiatan akademik melalui berbagai cara :

a. Fitur-fitur untuk menangani siswa dalam jumlah dari sedikit sampai sangat besar ( ratusan ribu)

b. Memfasilitasi kegiatan belajar secara online maupun blended learning (kombinasi belajar online dengan face-toface learning) c. Pembelajaran kolaboratif menggunakan modul - modul aktivitas seperti forum, database dan wiki.

\section{Analisis Permasalahan}

Permasalahan utama yang akan dibahas dalam penelitian ini adalah penerapan pembelajaran online menggunakan aplikasi e-learning Edmodo dan web sekolah di SMKN XYZ Bandung ternyata redundan karena fitur-fitur yang dimiliki kedua aplikasi tersebut hampir sama, sehingga guru harus mengupload file materi atau tugas ke Edmodo dan web sekolah untuk memastikan file tersebut dapat diakses oleh siswa. Hal yang sama berlaku juga untuk siswa karena siswa harus memastikan untuk mengecek kedua website tersebut untuk dapat mengakses file yang disediakan oleh guru. Dari segi maintenance, hal ini juga merepotkan untuk admin karena harus mengurus kedua website ini padahal kegunaannya kurang lebih sama. Sehingga dibutuhkan sebuah media e-learning yang dapat mendukung pembelajaran online dan juga memiliki fitur-fitur yang dibutuhkan sekolah, termasuk fitur-fitur yang dibutuhkan sekolah namun tidak tersedia pada Edmodo dan web sekolah.

Tabel 1. Gap Antara Tujuan dengan Keadaan Sekarang

\begin{tabular}{|c|c|c|}
\hline \multicolumn{3}{|c|}{ Gap } \\
\hline No & $\begin{array}{c}\text { Tujuan yang ingin } \\
\text { dicapai }\end{array}$ & Keadaan sekarang \\
\hline 1 & $\begin{array}{c}\text { Penggunaan satu } \\
\text { media } e \text {-learning } \\
\text { dengan fitur-fitur yang } \\
\text { dapat menyediakan } \\
\text { akses ke media } e \text { - } \\
\text { learning untuk materi } \\
\text { pembelajaran, tugas, } \\
\text { kuis dan pengumuman } \\
\text { maupun informasi } \\
\text { penting lainnya. }\end{array}$ & $\begin{array}{l}\text { Guru harus mengupload } \\
\text { dan siswa harus } \\
\text { mengecek Edmodo dan } \\
\text { web sekolah untuk } \\
\text { mengakses materi dan } \\
\text { informasi lainnya. }\end{array}$ \\
\hline 2 & $\begin{array}{l}\text { Kelancaran informasi } \\
\text { antara guru dan siswa } \\
\text { di luar sekolah dan } \\
\text { kepastian siswa } \\
\text { menerima informasi } \\
\text { tersebut }\end{array}$ & $\begin{array}{c}\text { Penerimaan informasi } \\
\text { tidak dapat dipastikan } \\
\text { karena siswa malas } \\
\text { mengecek media } \\
\text { informasi. }\end{array}$ \\
\hline
\end{tabular}

Untuk merealisasikan kebutuhan tersebut, ada beberapa cara yang dapat digunakan dalam menyediakan media e-learning yang diperlukan, yaitu sebagai berikut (Cincom System 2008) :

1. To Build, dimana organisasi mengembangkan aplikasi custom-built: 
a. Mengembangkan aplikasi sendiri.

b. Memperbaiki aplikasi yang telah ada.

2. To Buy, dimana organisasi menggunakan outsource:

a. Membeli software dari vendor

b.Menggunakan aplikasi open source lainnya.

Pendekatan yang paling tepat untuk SMKN XYZ Bandung adalah dengan menggunakan aplikasi open source, karena untuk mengembangkan ataupun memperbaiki aplikasi sendiri berarti membutuhkan tenaga kerja, waktu dan biaya yang tidak dimiliki oleh SMKN XYZ Bandung. Sedangkan dilihat dari keterbatasan segi biaya dan kelengkapan fitur LMS open source yang meskipun tidak selengkap LMS berbayar namun sudah dapat memenuhi kebutuhan SMKN XYZ Bandung, yaitu yaitu untuk pemberian materi online, diskusi online, penugasan online, kuis online serta pengumuman online.

\section{Perancangan dan Implementasi Sistem}

Hasil pemetaan kebutuhan SMKN XYZ didapatkan berdasarkan analisis masalah, dimana daftar kebutuhan fitur yang diperlukan untuk mendukung kegiatan belajar-mengajar di SMKN XYZ Bandung dapat disimpulkan ke 5 kebutuhan utama yaitu sebagai berikut:

Tabel 2 Kriteria daftar kebutuhan fitur SMKN XYZ Bandung

\begin{tabular}{|c|c|c|}
\hline $\begin{array}{c}\text { Fitur yang } \\
\text { Dibutuhkan } \\
\end{array}$ & Kebutuhan Utama & Deskripsi \\
\hline Create class/group & \multirow{15}{*}{$\begin{array}{l}\text { Pemberian materi } \\
\text { online }\end{array}$} & \multirow{15}{*}{$\begin{array}{c}\text { Menyediakan fitur } \\
\text { untuk guru dapat } \\
\text { memberikan } \\
\text { materi pelajaran } \\
\text { secara online } \\
\text { ketika guru yang } \\
\text { bersangkutan } \\
\text { berhalangan hadir } \\
\text { di kelas }\end{array}$} \\
\hline $\begin{array}{l}\text { Invite students/ } \\
\text { connect to teacher }\end{array}$ & & \\
\hline $\begin{array}{l}\text { Edit/ Delete class/ } \\
\text { group }\end{array}$ & & \\
\hline Profile page & & \\
\hline User Management & & \\
\hline Online group chat & & \\
\hline $\begin{array}{l}\text { Messaging/ } \\
\text { chatting }\end{array}$ & & \\
\hline Glossary & & \\
\hline Diverse & & \\
\hline Repositories & & \\
\hline Library/ Database & & \\
\hline Math Equation & & \\
\hline Custom themes & & \\
\hline $\begin{array}{l}\text { Post dan download } \\
\text { materi }\end{array}$ & & \\
\hline Edit/ Delete materi & & \\
\hline $\begin{array}{l}\text { Post dan download } \\
\text { tugas }\end{array}$ & \multirow{2}{*}{ Penugasan online } & \multirow{2}{*}{$\begin{array}{c}\text { Menyediakan fitur } \\
\text { untuk guru dalam } \\
\text { memberikan tugas } \\
\text { secara online }\end{array}$} \\
\hline Edit/ Delete tugas & & \\
\hline $\begin{array}{l}\text { Create quiz/ test } \\
\text { Upload quiz/ test }\end{array}$ & Kuis online & Menyediakan fitur \\
\hline
\end{tabular}

\begin{tabular}{|c|c|c|}
\hline $\begin{array}{l}\text { Pelaksanaan kuis/ } \\
\text { test }\end{array}$ & & $\begin{array}{l}\text { bagi guru untuk } \\
\text { melaksanakan }\end{array}$ \\
\hline $\begin{array}{l}\text { Edit/ Delete quiz/ } \\
\text { test }\end{array}$ & & kuis secara online \\
\hline $\begin{array}{l}\text { Message board } \\
\text { (pengumuman/ } \\
\text { informasi) }\end{array}$ & \multirow{6}{*}{$\begin{array}{l}\text { Pengumuman } \\
\text { online }\end{array}$} & $\begin{array}{c}\text { Memberikan } \\
\text { pengumuman dan } \\
\text { informasi penting }\end{array}$ \\
\hline Edit/ Delete & & yang \\
\hline Message board & & bersangkutan \\
\hline Create event & & dengan mata \\
\hline Edit/ Delete event & & pelajaran dan \\
\hline Berita sekolah & & $\begin{array}{c}\text { kegiatan belajar- } \\
\text { mengajar serta } \\
\text { berita sekolah }\end{array}$ \\
\hline \multirow{2}{*}{$\begin{array}{l}\text { Create discussion } \\
\text { Reply/comment to } \\
\text { discussion }\end{array}$} & & Menyediakan fitur \\
\hline & Diskusi online & $\begin{array}{c}\text { bagi siswa untuk } \\
\text { bertanya jika ada } \\
\text { topik yang tidak } \\
\text { di-mengerti dan } \\
\text { wadah diskusi } \\
\text { antara guru dan } \\
\text { siswa }\end{array}$ \\
\hline
\end{tabular}

Berdasarkan tabel diatas beserta hasil penelitian yang dilakukan di SMKN XYZ Bandung, dimana SMKN XYZ telah menggunakan dua aplikasi e-learning, hasil perbandingan kinerja antara Edmodo dan website sekolah berdasarkan fitur-fitur yang digunakan dapat dilihat pada tabel 3 di bawah ini. Responden adalah $60 \%$ siswa aktif di SMKN tersebut.

Tabel 3 Perbandingan Kinerja Fitur Edmodo dan website sekolah

\begin{tabular}{lll}
\hline $\begin{array}{l}\text { Fitur yang } \\
\text { dibutuhkan }\end{array}$ & Edmodo & $\begin{array}{l}\text { Website } \\
\text { sekolah }\end{array}$ \\
\hline $\begin{array}{l}\text { Pengumuman } \\
\text { online }\end{array}$ & $\begin{array}{l}\text { Sangat baik } \\
(42.9 \%)\end{array}$ & $\begin{array}{l}\text { Kurang } \\
(42.9 \%)\end{array}$ \\
\hline $\begin{array}{l}\text { Pemberian materi } \\
\text { online }\end{array}$ & Baik (57.1\%) & $\begin{array}{l}\text { Kurang } \\
(71.4 \%)\end{array}$ \\
\hline Diskusi online & $\begin{array}{l}\text { Sangat baik } \\
(57.1 \%)\end{array}$ & $\begin{array}{l}\text { Kurang } \\
(71.4 \%)\end{array}$ \\
\hline $\begin{array}{l}\text { Pemberian tugas } \\
\text { online }\end{array}$ & Baik (42.9\%) & $\begin{array}{l}\text { Cukup } \\
(42.9 \%)\end{array}$ \\
\hline Kuis online & Baik (55\%) & - \\
\hline
\end{tabular}

Dari data yang dikumpulkan dari responden, juga dapat disimpulkan bahwa kinerja berdasarkan fitur yang digunakan dari Edmodo lebih baik daripada website sekolah, dan tingkat kepuasan user untuk Edmodo juga lebih tinggi daripada website sekolah. Selain itu ada kriteria tambahan yang dinilai oleh user yaitu interface yang menarik, kemudahan penggunaan (userfriendliness) dan juga kelengkapan fitur yang dibutuhkan, dan juga kurangnya fitur yang dibutuhkan pada Edmodo dan website sekolah yaitu fitur chatting.

Dari analisis terhadap arus data dan kebutuhan di SMKN tersebut didapat alur data yang diolah 
jadi arsitektur informasi seperti dipaparkan dalam gambar 1 .

\begin{tabular}{|c|c|c|c|c|c|c|}
\hline & 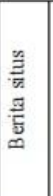 & 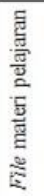 & 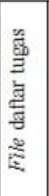 & 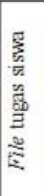 & 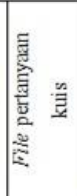 & 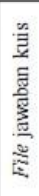 \\
\hline Memasang pengumuman & C & & & & & \\
\hline Meng-upload flle materi & $\mathrm{U}-$ & $-\mathrm{C}$ & & & & \\
\hline Men-download file materi & & $\psi$ & & & & \\
\hline Memulai diskusi & & $\hat{\mathrm{U}}$ & & & & \\
\hline Memberikan tugas & & & C & & & \\
\hline Mengumpulkan tugas & & & $\mathrm{U}-$ & $\mathrm{C}$ & & \\
\hline Meng-upload daftar pertanyaan kuis & & & & & $\mathrm{C}$ & \\
\hline Meng-upload jawaban kuis & & & & & U $\rightarrow$ & $\mathrm{C}$ \\
\hline
\end{tabular}

Gambar 1. Arsitektur Informasi

Huruf "C" untuk Create menandakan proses yang menghasilkan suatu data dan huruf " $U$ " untuk Use menandakan proses yang menggunakan data. Selanjutnya tabel diatas dapat dikonversi menjadi pemetaan kluster kebutuhan fitur pengolahan informasi seperti dapat dilihat pada gambar 2.

\begin{tabular}{|c|c|c|c|c|c|c|}
\hline & 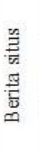 & 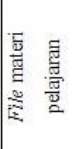 & 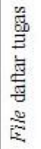 & 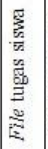 & 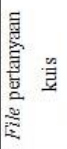 & 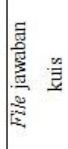 \\
\hline Memasang pengumuman & \multirow{4}{*}{\multicolumn{2}{|c|}{$\begin{array}{c}\text { Pemberian } \\
\text { materi \& } \\
\text { diskusi }\end{array}$}} & & & & \\
\hline Meng-upload file materi & & & & & & \\
\hline Men-download file materi & & & & & & \\
\hline Memulai diskusi & & & & & & \\
\hline Memberikan tugas & & & \multirow{2}{*}{\multicolumn{2}{|c|}{$\begin{array}{c}\text { Pemberian } \\
\text { tugas }\end{array}$}} & & \\
\hline Mengumpulkan tugas & & & & & & \\
\hline Meng-upload daftar pertanyaan kuis & & & & & \multirow{2}{*}{\multicolumn{2}{|c|}{ Kuis online }} \\
\hline Meng-upload jawaban kuis & & & & & & \\
\hline
\end{tabular}

Gambar 2 Arsitektur Informasi berdasarkan Kluster Fungsi

Setelah melakukan analisis arsitektur informasi, tahap berikutnya adalah pemilihan software LMS open source. Karena belum adanya penelitian tentang bagaimana memilih software open source LMS yang tepat dan kriterianya, maka kriteria pemilihan software menggunakan kriteria untuk memilih open source ERP, namun sebelum mengkomparasikan software pada kriteria yang ada, dibutuhkan beberapa calon software. Calon software open source diambil dari banyaknya jumlah download pada situs penyedia software open source terbesar di dunia, SourceForge.com, pada tanggal 21 Juni 2015.
Tabel 4 Hasil Survei LMS open source dengan download terbanyak

\begin{tabular}{lc}
\hline Software ERP Open Source & $\begin{array}{c}\text { Jumlah Download } \\
\text { Mingguan }\end{array}$ \\
\hline Moodle & 674 \\
\hline eFront & 541 \\
\hline ATutor & 199 \\
\hline ILIAS LMS & 51 \\
\hline
\end{tabular}

Selanjutnya akan dijabarkan mengenai perbandingan kemudahan penggunaan antara Moodle, ATutor dan ILIAS untuk memberikan ilustrasi bagaimana LMS Moodle ditandai lebih baik dari sisi kemudahan pengguna dibandingkan dengan ATutor dan ILIAS pada gambar 3 berikut ini :
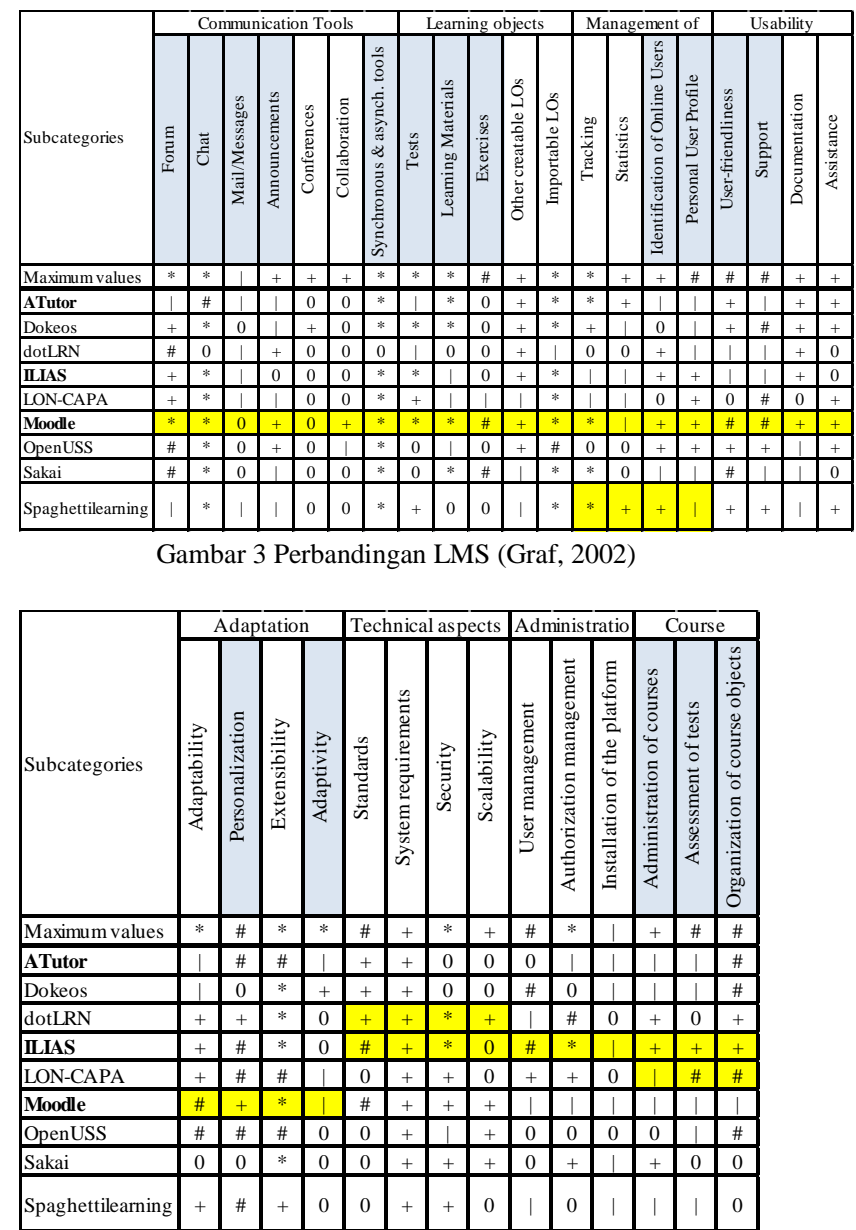

Gambar 3 Perbandingan LMS (Graf, 2002) (Lanjutan)

Perbandingan LMS open source ini merupakan hasil penelitian dari Sabine Graf dan Beate List yang dibiayai oleh European Social Fund (ESF) tentang evaluasi dan komparasi LMS berbasis open source. Dalam penelitian ini digunakan mentode QWS (Qualitative Weight and Sum) untuk melakukan evaluasi terhadap aplikasi 
atau software yang dinilai. Metode ini melakukan perhitungan terhadap bobot (weight) dengan menggunakan enam simbol kualitatif yang diurutkan sesuai dengan tingkat kepentingan (importance level) yaitu E (Essential), * (Extremely Valuable), \# (Very Valuable), + (Valuable), | (Marginally Valuable), 0 (Not Valuable). Dalam metode ini pihak peneliti dapat menetapkan sendiri nilai maksimal (maximum value) yang digunakan, tidak harus Essential yang tertinggi, dapat juga digunakan indeks Very Valuable. Terdapat 8 kategori yang akan dievaluasi yaitu Communication Tools, Learning Objects, Management of User Data, Usability, Adaptation, Tehnical Aspect, Administration dan Course Management. Setiap kategori lebih jauh lagi dibagi menjadi sub - sub kategori, sebagai contoh di kategori Communication Tools terdapat subkategori fitur forum, chat, announcements, conferences, collaboration, mail/message, dan synchronous/asynchronous tools.

Dari gambar 3 diatas dapat dilihat bahwa secara umum Moodle memiliki nilai evaluasi paling tinggi, terutama di kategori Communication Tools, Learning Objects, Management of User Data, Usability, dan Adaptation. ILIAS dan Dokeos di urutan kedua dan ketiga, sedangkan urutan keempat adalah Atutor, LON-CAPA, Spaghettilearning dan Open USS. Sakai dan dotLRN ada di posisi terakhir.

Dilihat dari antar muka yang ada dari ketiga LMS open source yang ada, LMS Moodle memiliki antar muka yang lebih menarik dan mudah untuk digunakan oleh semua user, guru dan siswa. Moodle lebih cocok digunakan sebagai LMS di SMKN XYZ karena memiliki keunggulan seperti dapat menggunakan bahasa Indonesia sebagai bahasa antarmuka utamanya. Hal ini penting karena LMS ini akan diterapkan di SMK yang menggunakan bahasa Indonesia sebagai bahasa pengantar utamanya. Selain itu guru-guru juga umumnya lebih mengerti bahasa Indonesia dibandingkan dengan bahasa lainnya.

\section{Implementasi dan Pengujian}

Setelah proses perancangan, tahap berikutnya adalah tahap implementasi dan pengujian. Proses implementasi merupakan proses penerapan perangkat software pada sebuah organisasi sesuai dengan yang telah direncanakan sebelumnya.
Pendekatan metode implementasi yang digunakan adalah menggunakan pendekatan "Pilot", yaitu pendekatan yang mengimplementasikan versi kecil dari sistem akhir. Pendekatan ini setara dengan test drive dari sistem yang digunakan, namun hanya memilih beberapa area dan dampaknya dapat dikelola lebih cermat.

Dalam sistem ini terdapat tiga jenis hak akses. Pertama adalah administrator yang memiliki akses ke semua modul yang terdapat dalam Moodle, lalu guru yang dapat mengatur konten dalam Moodle serta siswa. Hasil implementasi dari Moodle dapat dilihat dari Gambar 4 sampai Gambar 8 di bawah. Gambar 4 menunjukkan halaman awal dari Moodle SMKN XYZ Bandung, dimana user dapat memilih pilihan log in sebagai admin, student atau teacher, ataupun hanya sebagai guest.

User dapat melakukan login berdasarkan role yang telah diberikan. Privilege atas system setting ditentukan berdasarkan peran user yang bersangkutan. Admin dan teacher dapat menambah dan mengedit kelas, sedangkan student hanya dapat melakukan proses enroll di kelas dan mengikuti kelas tersebut.

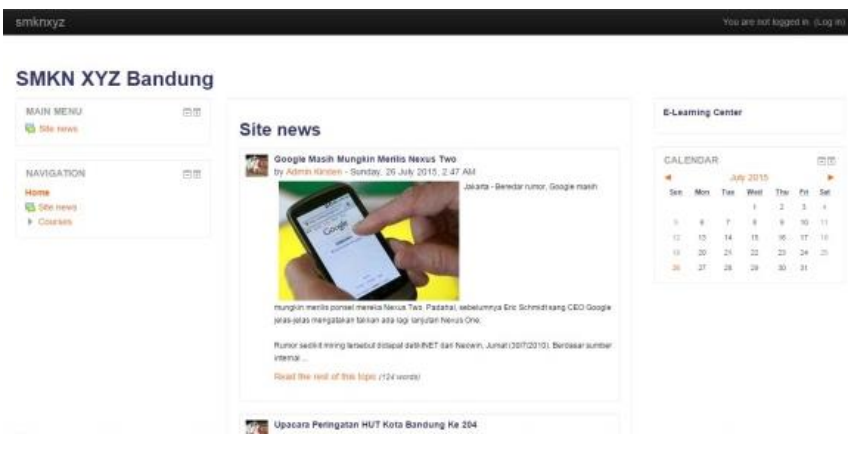

Gambar 4 Halaman Awal Moodle

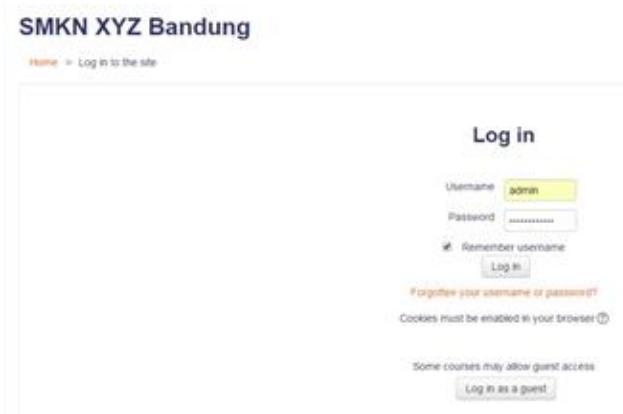

Gambar 5 Halaman Login 


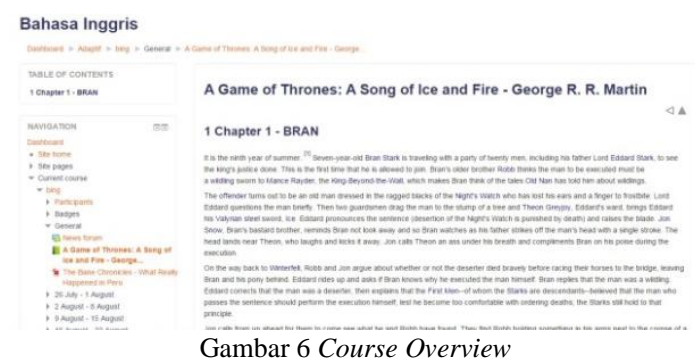

Di dalam setiap kelas (course), tersedia beberapa pilihan fungsi upload file (file picker), termasuk di dalamnya fungsi pemberian materi online (books, files), fungsi penugasan online (assignment), fungsi kuis online (quiz), fungsi diskusi online (forum) bahkan fungsi chat. Gambar 6 menampilkan contoh tampilan materi yang diupload ke Moodle.

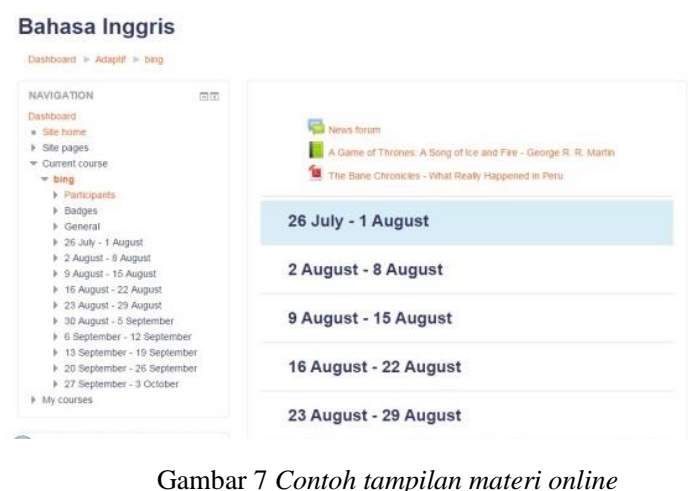

Fungsi penugasan online dapat dilakukan dalam dua cara yaitu, penambahan tugas secara manual dan unggah tugas dari file system baik dari private files di Moodle, PC/laptop, internet (URL download) dan lain sebagainya. Terdapat juga fitur Forum diskusi dapat diikuti oleh guru dan siswa dalam suatu course tertentu, dan fungsi ini khususnya bermanfaat ketika siswa mempunyai pertanyaan yang ingin ditanyakan ke guru ataupun sesama teman mengenai pelajaran yang bersangkutan. Selain itu Guru dapat memberikan kuis secara online dengan menambahkan kuis di course tertentu. Guru juga dapat mengatur waktu, bobot penilaian dan jenis pertanyaan dalam fitur ini seperti terlihat di gambar 8 .

Beberapa fitur lain yaitu fitur messaging yang dapat dilakukan baik oleh guru dan siswa, guruguru, guru-siswa dan juga siswa-siswa. Ketika user melakukan login ke situs Moodle, user tersebut secara otomatis akan muncul di daftar Online Users. Dan ada juga fitur news dimana guru dapat mengunggah link - link yang berisi berita yang dapat berguna untuk proses pembelajaran para siswa.

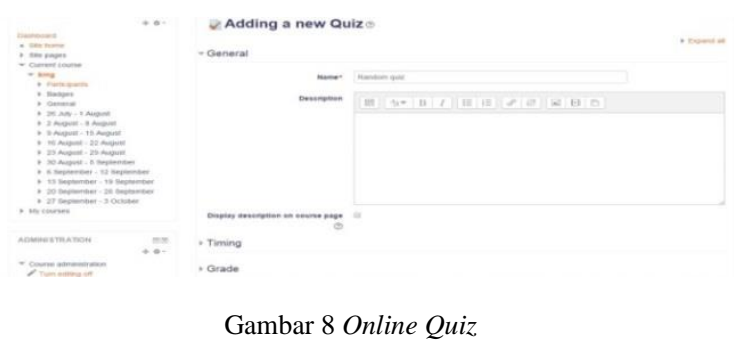

\section{Kesimpulan dan Saran}

\subsection{Kesimpulan}

Berdasarkan penelitian yang dilakukan, maka kesimpulan yang dapat diambil adalah:

1. Berdasarkan hasil wawancara dan kuesioner didapatkan 5 kategori kebutuhan utama yang dibutuhkan SMKN XYZ berkaitan dalam penggunaan elearning, yaitu: pemberian materi online, diskusi online, penugasan online, kuis online dan pengumuman online.

2. Penggunaan Learning Management System Moodle dapat mendukung kegiatan pembelajaran online dan memenuhi 5 kebutuhan utama SMKN XYZ, dengan menyediakan fitur-fitur yang dibutuhkan seperti akses terhadap materi pembelajaran, tugas, kuis, diskusi online juga informasi penting lainnya, termasuk fitur-fitur yang dibutuhkan sekolah namun tidak tersedia pada Edmodo dan website sekolah, seperti fitur chatting dan math equation.

\subsection{Saran}

Beberapa saran berikut diberikan berdasarkan penelitian yang telah dilakukan, yaitu:

1. Pihak sekolah disarankan untuk membuat kebijakan pembagian role terhadap guru, karena pada Moodle terdapat dua jenis guru, yaitu guru yang dapat mengedit Course dan non-editting teacher, sehingga hanya guru-guru yang kelasnya menggunakan Moodle dapat mengedit daftar kelas tersebut.

2. Pihak sekolah dapat menggunakan fitur baru Moodle, yaitu Moodle Mobile application untuk menginformasikan 
kepada siswa secara mobile bila adanya pengumuman pada Moodle.

\section{Referensi}

Ellis, Ryan, K 2009, A Field Guide to Learning Management System. American Society for Training and Development, Alexandria, USA. Cincom System Inc 2008, To Build or Buy? A Question of Application Development for Compliance and Quality Systems, Cincom Systems, USA.
Graf, Sabine, List, Beate 2002, 'An Evolution of Open Source Platforms Stressing Adaptation Issues', ICALT '05 Proceedings of the Fifth IEEE International Conference on Advanced Learning Technologies, pp.163-165.

Siahaan, Sudirman 2002, 'Penjajakan tentang Kemungkinan Pemanfaatan Internet untuk Pembelajaran di SLTA di Wilayah Jakarta dan Sekitarnya', Jurnal Pendidikan dan Kebudayaan Badan Penelitian dan Pengembangan Departemen Pendidikan Nasional Jakarta., vol.8, no. 39. 